\title{
Alginate-Based Edible Coatings Enriched with Cinnamon Essential Oil Extend Storability and Maintain the Quality of Strawberries under Tropical Condition
}

\author{
DOI: $10.18196 /$ pt.v9i1.10368
}

\author{
Putri Wahyuni Siburian ${ }^{1,2 *}$, Moh. Affan Fajar Falah ${ }^{1}$, Jumeri Mangunwikarta ${ }^{1}$ \\ ${ }^{1}$ Department of Agro-Industrial Technology, Faculty of Agricultural Technology, Universitas Gadjah Mada \\ Jalan Flora No. 1 Bulaksumur, Yogyakarta, Indonesia \\ ${ }^{2}$ IMRD, Bioscience Engineering, Ghent University-Coupure links 6539000 Gent, Belgium \\ *Corresponding author: PutriWahyuni.Siburian@UGent.be
}

\begin{abstract}
Strawberries are often transported and sold without temperature control, which causes huge losses due to rapid decay and quality deterioration. In this study, the effectiveness of edible coatings using alginate and enriched with an antibacterial agent (cinnamaldehyde from Cinnamomum burmannii essential oil), to maintain the quality and shelf life of strawberry was examined. Alginate coatings were prepared by dissolving 2\%(W/V) sodium alginate, 0.5\%(V/V) glycerol, 0.1\%(W/V) CMC, and 0.5\% (w/V) stearic acid, while antimicrobial agent was prepared by homogenizing 0.5\%(v/V) cinnamon essential oil and 0.2\%(V/V) Tween 20. Physicochemical and biochemical attributes [weight loss, firmness, color ( $\left.L^{*}, a^{*}, b^{*}\right)$, soluble solids content, vitamin Closs, acidity level, odor, total yeast and molds, and total mesophilic microorganisms were analyzed during storage under tropical conditions at $27 \pm 2{ }^{\circ} \mathrm{C}$. Statistical analysis was performed using ANOVA followed by a Tukey test. The inhibitory activity of antimicrobial agent was evaluated using the disc diffusion method. An alginate-based coatings enriched with Cinnamomum burmannii essential oil (AL+CBEO) was effective in maintaining physicochemical quality attributes and reducing the number of spoilage microorganisms, while alginate coatings alone (AL) found to be optimal for vitamin C loss prevention and additionally exhibited a more desirable odor. Overall, strawberry stored under tropical conditions appeared to be better preserved by alginate-based coatings enriched with cinnamon essential oil.
\end{abstract}

Keywords: Antimicrobial agent, Edible coatings, Quality attributes, Strawberry, Tropics

\begin{abstract}
ABSTRAK
Stroberi pada umumnya didistribusi dan dijual tanpa pengendalian suhu yang menyebabkan terjadinya kerusakan yang cepat dan penurunan kualitas dalam jumlah besar. Pada penelitian ini, keefektifan pelapis edible dengan Alginat coating saja atau yang diperkaya dengan agen antibakterial (cinnamaldehyde dari minyak essensial Cinnamomum burmannii) untuk mempertahankan mutu dan umur simpan stoberi telah diuji dan dianalisis. Alginat coating dibuat dengan menggunakan CMC 0,1\%(w/v), sodium alginat 2\%(w/V), gliserol 0,5\%(v/v), dan asam stearat 0,5\% (w/v), sementara agen antimikrobia dibuat dengan mencampurkan cinnamon essential oil 0,5\%(v/V) dan Tween 20 0,2\%(v/V). Atribut fisikokimia dan biokimia [susut bobot, tekstur, warna (L*, $\left.a^{*}, b^{\star}\right)$, total padatan terlarut, penyusutan kandungan vitamin C, tingkat keasaman, aroma, total yeast and molds, dan total mikroorganisme aerobik mesofilik] telah dianalisis selama masa penyimpanan pada suhu tropis yakni $(27 \pm 2)^{\circ} \mathrm{C}$. Analisis statistik dilakukan dengan menggunakan ANOVA yang kemudian dilanjutkan dengan uji Tukey. Aktivitas penghambatan oleh agen antimikroba dievaluasi menggunakan metode difusi cakram. Hasil penelitian ini menunjukkan bahwa alginat coating yang diperkaya dengan minyak essensial kayu manis terbukti efektif mempertahankan atribut fisikokimia dan mampu mengurangi jumlah mikroorganisme perusak, dilain hal pelapis edibel dengan alginat saja terbukti bekerja lebih baik dalam mencegah penurunan kandungan vitamin C dan juga memperoleh tingkat preferensi aroma yang lebih baik. Berdasarkan hasil pengujian atribut kualitas secara keseluruhan ( $P<0.05)$, stroberi pada lingkungan tropis lebih awet ketika dilapisi alginat coating yang diperkaya minyak essensial kayu manis.
\end{abstract}

Kata Kunci: Agen antimikrobia, Atribut kualitas, Fragaria x ananassa, Pelapis edibel, Tropik

\section{INTRODUCTION}

Postharvest treatments of strawberries in the texture softening, physiological disorders and infectropics, lower-middle income, and developing tion caused by several pathogens that can rapidly countries are not well-managed and mostly done reduce the quality of fruit (Gol et al., 2013; K. D. in conventional ways. Strawberries are usually sold Vu et al., 2011). According to FDA, strawberries without any temperature control, leading to rapid stored in the counter/pantry last only for about ripening and massive quality losses. Strawberry has a very short shelf-life and senescence period due to its susceptibility to mechanical injury, excessive 1-2 days. However, strawberries can last in cold storage $\left(0^{\circ} \mathrm{C}\right)$ and under commercialization storage $\left(20^{\circ} \mathrm{C}\right)$ for up to 2 weeks and for about 3-4 days, 
respectively (Romanazzi, 2010). Hence, appropriate postharvest treatments are a great use for the prevention of serious economic losses due to spoiling.

Various technologies have been developed for strawberry preservation. Study on edible film and coating has undergone a rapid expansion in the past twenty years due to increased consumer interest in health, nutrition, food safety, and environmental issues (Espitia et al., 2014). Coating techniques can be potentially used to extend shelflife and maintain the quality of foods by preventing changes in aroma, taste, texture, and appearance (Tharanathan \& Kittur, 2003; Gol et al., 2013).

In recent years, there has been much attention on carrageenan and alginate as sources in edible film formation (Cian et al., 2014). According to FDA, carrageenan and alginates are GRAS materials, thereby, they have been passed the mentioned standards and are considered as edible films and coatings. Alginate is an appealing film-forming compound because of its non-toxicity, biodegradability, biocompatibility, and low price (C. H. T. $\mathrm{Vu} \&$ Won, 2013). Alginate coating is the salt of alginic acid and a polymer of D-mannuronic acid and L-guluronic acid (Guerreiro et al., 2015) that is derived from brown seaweed of the family Phaeophyceae (Nair et al., 2020). The main advantage of alginate is its usage in the production of edible films due to its unique colloidal properties and its ability to form strong gels or insoluble polymers (Fan et al., 2009). It has been shown that the applications of alginate coating on fruits will enhance the shelf-life of strawberry, such as a study conducted by Nazoori et al. (2020). To date, alginate's functional properties such as thickening, stabilizing, suspending, film-forming, gel-producing, and emulsion-stabilizing have been well studied, for example, the study done by Tavassoli-Kafrani et al. (2016) and Zactiti \& Kieckbusch (2006).

In edible coating development, besides the coating materials, an antimicrobial is often added to the solution to maximize the usability of the coating. The antimicrobial activity of essential oils has been widely recognized for decades and intensively explored in recent years, driven by the search for naturally-derived alternatives to synthetic food additives (Seow et al., 2014). A wide variety of antimicrobials have been added to edible films and coatings to control microbiological growth and extend shelf-life. Among them, cinnamon essential oil has demonstrated a high and broad-spectrum antimicrobial activity and exhibited great fungal inhibition (Chao et al., 2000). Several reports have shown the promising effect of cinnamon essential oils against several species of bacteria such as Staphylococcus aureus, Listeria monocytogenes, Escherichia coli, Bacillus cereus, and Salmonella typhimurium (Raeisi et al., 2015). Further, the antimicrobial effect of cinnamon essential oil against various bacteria such as E. coli, Pseudomonas aeruginosa, Enterococcus fecalis, S. aureus, Salmonella sp., and Vibrio parahaemolyticus have been reported as well, as reported by a study conducted by Raeisi et al. (2015), reporting that cinnamon essential oil had antibacterial effect against both E. coli and S. aureus.

Based on the rationales mentioned above, hence, the objectives of this study were to evaluate the effectiveness of edible coatings with alginate alone and/or enriched with an antibacterial agent in extending the shelf life and maintaining the quality of strawberries. This study is expected to be able to provide a relevant reference for future study. By reporting the result of this study, we aim to support the idea of using edible coating technique into strawberry commercialization.

\section{MATERIALS AND METHODS}

Strawberries were directly harvested from the strawberries farm center near Mountain Merbabu in Ketep Pass, Central Java, Indonesia (altitude $841 \mathrm{~m}$ above sea level with an average temperature of $21-25^{\circ} \mathrm{C}$ and humidity of $\left.73-88 \%\right)$. The straw- 
berries were harvested based on their physical appearance, approximately around 6-8 weeks after flowering. Perfectly ripe strawberries (100\% red surface color), which were identical in color and size without any physical injuries and/or disease symptoms, were selected for the experiment. All coatings materials used were analytical and food grade, including sodium alginate (Wako pure chemical industries, Ltd, Japan), 87\% glycerol (Merck, Darmstadt, Germany), Carboxymethyl Cellulose (CMC) (Sinar Kimia, Indonesia), stearic acid from palm oil derivatives (Merck, Darmstadt, Germany), and Tween 20 (Merck, Darmstadt, Germany). CBEO extraction was obtained via custom order from authorized essential oil industry, Lansida group, Indonesia.

\section{Coating solutions}

The solution was prepared based on suggested coating material in previous literature, while the concentration was determined based on the concentrations reported to have significant effect in previous studies (Chiumarelli \& Hubinger, 2014; Han et al., 2017; Martiñon et al., 2014; Zhang et al., 2015). Alginate coatings were prepared by dissolving $0.1 \%(\mathrm{w} / \mathrm{v}) \mathrm{CMC}, 2 \%(\mathrm{w} / \mathrm{v})$ sodium alginate, $0.5 \%(\mathrm{v} / \mathrm{v})$ glycerol, and $0.5 \%(\mathrm{w} / \mathrm{v})$ stearic acid, while the antimicrobial agent was prepared by homogenizing $0.5 \%(\mathrm{v} / \mathrm{v})$ cinnamon essential oil and $0.2 \%(\mathrm{v} / \mathrm{v})$ Tween 20 . In this study, the coating procedure was performed with dipping method. In this method, a thin membranous film is formed over the fruit surface by directly dipping the product into the aqueous medium of coating formulations, removing, and allowing to air dry (Tavassoli-Kafrani et al., 2016)

\section{Weight loss}

The strawberries were washed with flowing water and drained for about 30 minutes. The same three batches of strawberries per treatment (non- destructive assay) were weighed at the beginning of the experiment (shortly after the coating were settled) and at the end of every storage interval during the observation period. The difference between the initial and final weight of fruit is considered as a total weight loss, and the result is expressed as the percentage loss. The initial weight means the weight of the strawberry on the previous assessment $(n-1)$ and the final weight means the weight on the day of assessment (n). Weight loss (\%) is expressed using the formula (1):

Weight loss $(\%)=($ initial weight-final weight $) /$ (initial weight) $\mathrm{x} 100$

\section{Firmness}

Firmness is expressed as the maximum force ( $\mathrm{F}$ maximum) needed to penetrate the strawberries. The firmness was assayed by using a Penetrometer Fruit Hardness Tester type FHT 200, (Extech) within three replications using different group samples (destructive assay) for each measurement.

\section{Color}

The color was assessed by taking five samples from each treatment into testing. Assessment was conducted every day during storage period. Color was observed by using the Chromameter AT-13-04 CR-400 Konica Minolta instrument, Japan with Hunter's Lab Colorimetric System. Therefore, the $L^{*}$ value for each scale indicates the level of light or dark, a* value for redness or greenness, and $b^{*}$ value for yellowness or blueness (Hunter Laboratories, 2012).

\section{Soluble Solids Content}

The soluble solids content was determined by measuring Refractive Index of strawberries using hand-held Refractometer 0-32\% (Brix, Atago Co, Japan). Strawberries that had been mashed were filtered with nylon screen, and a drop of juice 
was placed on the lens. The assay was performed in three replications per treatment with a single measurement.

\section{Citric acid content}

Acidity levels were examined using acid-base titration and expressed as a percent of dominant acid (\% citric acid). A five grams filtered strawberry extract was diluted into $100 \mathrm{~mL}$ distilled water, then $10 \mathrm{~mL}$ of liquid samples were taken into titration and homogenized with a vortex. The solution that had been mixed with 2 drops of indicator phenolphthalein $(0.1 \%(\mathrm{w} / \mathrm{v})$ in alcohol solvent beforehand was titrated with $\mathrm{NaOH} 0.1 \mathrm{~N}$. Titration took place until a light purple/pink color persisted, roughly after 20 seconds of swirling or to the endpoint of 8.1. The $\mathrm{NaOH}$ volume spent in titration was recorded and used to quantify acid content by using the formula (2):

$(\mathrm{V} \times \mathrm{N} \times 0.064 \times \mathrm{Fp}) /(\mathrm{m}$ aliquot $) \times 100 \%$

where $\mathrm{V}$ is the $\mathrm{mL}$ of $\mathrm{NaOH}$ spent for titration, $\mathrm{N}$ is the molarity of the $\mathrm{NaOH}, \mathrm{m}$ aliquot is the mass of the aliquot sample taken for analysis, and Fp is a dilution factor.

\section{Vitamin C}

Vitamin C content was determined using iodometric titration. This method determines the vitamin $\mathrm{C}$ content through redox titration using iodine. Samples were prepared with similar method to section 2.7. The solution that had been previously mixed with $1 \mathrm{~mL}$ of $1 \%(\mathrm{v} / \mathrm{v})$ indicator amylum was titrated with iodine $0.01 \mathrm{~N}$ until a russet color persisted, roughly after 20 seconds of swirling. Vitamin C content (g vitamin C/100g) was calculated using the formula (3):

(V iodine $\mathrm{x} \mathrm{N}$ x 0,88 x Fp x 100)/(m aliquot)

\section{Flavor testing}

The flavor was assessed with a sensory analysis by 30 untrained panelists. The panelists were asked to evaluate the flavor of each sample after one hour of coatings settlement. A batch of samples consisting of ten strawberries for each treatment, which were control, $2 \% \mathrm{AL}$, and $2 \% \mathrm{AL}+0.5 \% \mathrm{CBEO}$, were given to the panelist for scoring. Panelists assessed the samples using scoring form with a four-point hedonic scale, where a score of 1 represents most disliked and a score of 4 represents most liked.

\section{Microbial Growth Analysis}

Materials such as plate count agar (Oxoid Ltd, Basingstoke, England), Potato Dextrose Agar (potato extract, dextrose, agar, and distilled water), and nutrient broth (glucose, peptone, sodium chloride, yeast extract) were used for microbial analysis. The culture was made by incubating $0.5 \%(\mathrm{w} / \mathrm{v})$ strawberry extract into nutrient broth for 24 hours under steady temperature of $35^{\circ} \mathrm{C}$. The inhibition activities were observed based on diameter of clear zone formed on the plates. Microbial counts were then determined for each treatment. The number of aerobic mesophilic bacteria and the number of molds and yeasts were observed. Plate count agar was used for total aerobic and mesophilic organisms, while potato dextrose agar was used for total yeast and molds. The microbial culture that had been enumerated into several dilution series were inoculated onto agar plates with spread technique. Plates then were incubated for \pm 48 hours at $35^{\circ} \mathrm{C}$. To count the colonies, duplicate plates containing 25-250 colonies were taken to the calculation, and the number of microbial counts was expressed in $\log \mathrm{CFU} \mathrm{mL} \mathrm{m}^{-1}$. The calculation was performed using formula (4):

$$
\left.\mathrm{N}=\left(\sum \mathrm{C}\right) /([(1 \times \mathrm{n} 1)+(0,1 \times \mathrm{n} 2)] \times(\mathrm{d})\}\right) .
$$


where $\mathrm{N}=$ Number of colonies per $\mathrm{mL}$; $\square \mathrm{C}=$ Sum of all colonies on all plates counted; $\mathrm{n} 1=$ Number of plates in the first dilution counted; $\mathrm{n} 2=$ Number of plates in the second dilution counted; $\mathrm{d}=$ Dilution from which the first counts were obtained. (Maturin, L \& Peeler., 2001).

\section{Statistical Analysis}

IBM SPSS 2017 was used for data processing to determine the effect of coatings on quality attributes of strawberries. All data taken for further analysis must pass the normality and homogeneity test beforehand. Differences between treatments for every storage interval were tested for significance with ANOVA analysis (95\% confidence level) followed by post hoc Tukey test.

\section{RESULTS AND DISCUSSION}

Effect on fruits weight loss, firmness, and color

Weight loss in all samples significantly increased during storage at $27 \pm 2^{\circ} \mathrm{C}$. Weight loss on the uncoated samples was double $(\mathrm{P} \leq 0.05)$ compared to that on the coated ones. The highest total weight loss was $54.58 \%$, found in control samples, followed by $2 \%$ AL samples with $49.11 \%$ weight loss and the lowest was $27.71 \%$ found in $2 \% \mathrm{AL}+0.5 \% \mathrm{CBEO}$. Briefly, in terms of maintaining the weight of strawberries, $2 \% \mathrm{AL}+0.5 \% \mathrm{CBEO}$ performance was better than that of $2 \% A L$. Study by Guerreiro et al. (2015) also reported a similar result from the application of polysaccharide-based edible coatings on strawberries.

A Tukey test was performed to determine whether treatments were significantly different from each other, as shown in Table 1 . The result showed that weight loss of both control and $2 \% \mathrm{AL}$ samples was significantly higher than that in $2 \% \mathrm{AL}+0.5 \% \mathrm{CBEO}$ samples. However, the weight loss of control samples did not significantly lower than that of $2 \% A L$ samples. This happened due to the presence of high concentration of cinnamaldehyde found in cinnamon essential oil. These cinnamaldehyde acts as antibacterial agent that can prevent and/or reduce microorganism spoilage, meaning that it helps reduce quality deterioration including weight loss. Migration of water from the fruit to the environment is the major cause of weight loss in fruit during storage (Duan et al., 2011). Weight loss was lower in coated samples than uncoated samples because edible coating forms a thin layer on the surface of the coated strawberry and supplies an effective barrier to water, vapor, moisture, or temperature. In addition, edible coatings act as an extra layer, which also coats the stomata and leads to a decrease in transpiration and in turn, to a reduction in weight loss (Valero et al., 2013).

The tissue firmness was expressed as the amount of force $(F)$ needed to penetrate the strawberries, the harder the fruit the greater the force needed to penetrate the strawberries. Uncoated strawberry had the highest firmness decline, which was $96.19 \%$, followed by $2 \% A L$, which was $62.07 \%$, and $2 \% \mathrm{AL}+0.5 \% \mathrm{CBEO}$ had the lowest decline, which was $47.92 \%$ (Table 1). Therefore, coating with alginate alone or in combination with antimicrobial agents significantly $(\mathrm{P}<0.05)$ reduced firmness deterioration and delayed softening of strawberries. Even though in the beginning of the experiment firmness level varied between samples, but from day 2 to day 5, uncoated samples were always the softest, softer than $2 \% A L$, while $2 \% A L+0.5 \% C B E O$ was the hardest, as shown in Table 1 . Thus, this study confirmed that coatings treatment reduced firmness deterioration and delayed the softening of strawberry. During storage, firmness of the fruits is likely to soften due to several factors, including loss of cell turgidity pressure, loss of extracellular and vascular air, degradation of the cell wall, and consequent loss of water by the cell breakdown (Martinez-Ferrer et al., 2002) cited in (Del-Valle et 
Table 1. Effect of edible coating on selected attributes of strawberry during storage at $27 \pm 2^{\circ} \mathrm{C}$

\begin{tabular}{|c|c|c|c|c|}
\hline \multirow{2}{*}{ Component analysis } & \multirow{2}{*}{ Time (days) } & \multicolumn{3}{|c|}{ Treatments ( $\pm S D)$} \\
\hline & & Control & $2 \% A L$ & $2 \% A L+0.5 \%$ CBEO \\
\hline \multirow[t]{5}{*}{ Weight loss (\%) } & 1 & - & - & - \\
\hline & 2 & $15.23 b c \pm 0.71$ & $13.72 a \pm 0.84$ & $6.51 \mathrm{a} \pm 1.15$ \\
\hline & 3 & $15.40 c \pm 0.33$ & $15.95 \pm 0.78$ & $12.36 a \pm 1.07$ \\
\hline & 4 & $15.93 \pm 0.48$ & $14.59 \pm 0.76$ & $7.35 \pm 0.90$ \\
\hline & 5 & $24.66 \pm 0.77$ & $17.84 \pm 0.78$ & $4.76 \pm 0.82$ \\
\hline \multirow[t]{5}{*}{ Firmness (N) } & 1 & $4.47 \pm 0.21$ & $4.43 \pm 0.06$ & $4.57 \pm 0.31$ \\
\hline & 2 & $2.45 b c \pm 0.18$ & $4.00 \mathrm{ac} \pm 0.26$ & $4.57 a b \pm 0.23$ \\
\hline & 3 & $1.03 b c \pm 0.08$ & $2.97 a \pm 0.53$ & $3.60 a \pm 0.30$ \\
\hline & 4 & $0.57 b c \pm 0.38$ & $1.95 a \pm 0.39$ & $2.40 a \pm 0.26$ \\
\hline & 5 & $0.17 b c \pm 0.10$ & 1.68 a.c \pm 0.15 & $2.38 a b \pm 0.28$ \\
\hline \multirow[t]{5}{*}{ Lightness $\left(L^{*}\right)$} & 1 & $40.87 \pm 2.37$ & $42.50 \pm 2.56$ & $40.86 \pm 4.12$ \\
\hline & 2 & $35.29 \pm 1.67$ & $37.08 \pm 3.35$ & $40.25 \pm 3.67$ \\
\hline & 3 & $33.32 c \pm 2.89$ & $32.31 c \pm 1.07$ & 37.64 a.b \pm 2.09 \\
\hline & 4 & $29.81 c \pm 1.83$ & $30.65 c \pm 1.42$ & $34.75 a . b \pm 0.94$ \\
\hline & 5 & $32.53 \pm 4.74$ & $34.36 \pm 8.44$ & $34.63 \pm 2.24$ \\
\hline \multirow[t]{5}{*}{ Redness $\left(a^{*}\right)$} & 1 & $33.62 \pm 3.55$ & $31.51 \pm 2.24$ & $31.32 \pm 1.81$ \\
\hline & 2 & $31.12 \pm 1.28$ & $31.13 \pm 2.93$ & $30.76 \pm 2.92$ \\
\hline & 3 & $22.45 \pm 9.90$ & $26.71 \pm 2.44$ & $29.65 \pm 1.16$ \\
\hline & 4 & $18.28 c \pm 7.39$ & $25.37 \pm 3.50$ & $26.98 a \pm 2.75$ \\
\hline & 5 & $12.72 c \pm 6.72$ & $17.61 \pm 7.86$ & $24.59 a \pm 4.44$ \\
\hline \multirow[t]{5}{*}{ Yellowness (b*) } & 1 & $25.37 \pm 5.11$ & $25.83 \pm 3.76$ & $24.18 \pm 4.32$ \\
\hline & 2 & $17.79 \pm 4.08$ & $19.84 \pm 5.04$ & $21.54 \pm 4.58$ \\
\hline & 3 & $14.13 \pm 5.04$ & $13.10 \pm 2.12$ & $17.17 \pm 1.97$ \\
\hline & 4 & $9.74 c \pm 3.28$ & $10.57 c \pm 2.76$ & $15.36 a . b \pm 2.15$ \\
\hline & 5 & $8.94 \pm 4.27$ & $9.04 \pm 4.38$ & $14.33 \pm 3.14$ \\
\hline \multirow[t]{5}{*}{ Soluble solids (\%) } & 1 & $6.00 \pm 0.00$ & $6.00 \pm 0.00$ & $5.83 \pm 0.29$ \\
\hline & 2 & $6.77 \pm 0.25$ & $7.00 \pm 0.00$ & $7.00 \pm 0.00$ \\
\hline & 3 & $8.60 b . c \pm 0.17$ & $7.33 a \pm 0.29$ & $7.43 a \pm 0.12$ \\
\hline & 4 & $9.93 b . c \pm 0.12$ & $8.80 \mathrm{a} . \mathrm{c} \pm 0.20$ & $8.00 a \cdot b \pm 0.00$ \\
\hline & 5 & $10.93 b . c \pm 0.12$ & $10.07 a \cdot c \pm 0.12$ & $9.00 a \cdot b \pm 0.00$ \\
\hline \multirow[t]{5}{*}{ Citric acids (\%) } & 1 & $1.22 \pm 0.03$ & $1.24 \pm 0.03$ & $1.22 \pm 0.06$ \\
\hline & 2 & $1.09 b \pm 0.06$ & $1.24 a \pm 0.03$ & $1.15 \pm 0.00$ \\
\hline & 3 & $1.32 b . c \pm 0.03$ & $1.13 a \pm 0.03$ & $1.07 a \pm 0.03$ \\
\hline & 4 & $1.52 c \pm 0.03$ & $1.43 c \pm 0.03$ & $1.24 a . b \pm 0.03$ \\
\hline & 5 & $1.58 b . c \pm 0.03$ & $1.47 a . c \pm 0.00$ & $1.26 a . b \pm 0.03$ \\
\hline \multirow[t]{5}{*}{ Vitamin C (g ascorbic acid/100 9) } & 1 & $1.47 \pm 0.10$ & $1.38 \pm 0.05$ & $1.38 \pm 0.05$ \\
\hline & 2 & $1.32 \pm 0.15$ & $1.38 \pm 0.10$ & $1.38 \pm 0.10$ \\
\hline & 3 & $1.29 \pm 0.10$ & $1.29 \pm 0.05$ & $1.38 \pm 0.05$ \\
\hline & 4 & $1.20 \pm 0.13$ & $1.29 \pm 0.10$ & $1.23 \pm 0.09$ \\
\hline & 5 & $1.17 \pm 0.05$ & $1.26 \pm 0.05$ & $1.17 \pm 0.05$ \\
\hline
\end{tabular}

Remarks: a,b,c Means which are followed by a common superscript letter, are significantly different $(\mathrm{P}<0.05)$ using Tukey, $(\mathrm{a}=$ different with control, $b=$ different with $2 \% A L, c=$ different with $2 \% A L+0.5 \% C B E O)$. Each value is the mean for three replicates \pm STD. 
al., 2005). Loss of texture is dependent on both cell wall degradation and loss of turgidity of the tissue. The other component to tissue softening is a loss of turgor pressure, which falls with loss of water or desiccation due to transpiration and respiration (Bhaskara Reddy et al., 2000). The application of edible coating slow down the strawberry softening because of the film formation in the fruit surface, which acts as a barrier to $\mathrm{O} 2$ uptake, meaning that the coating could delay the metabolic activity and subsequently slow down the senescence process.

At the beginning of storage, values of lightness $\left(\mathrm{L}^{*}\right)$, redness $\left(\mathrm{a}^{*}\right)$, and yellowness $\left(\mathrm{b}^{*}\right)$ tended to vary between samples. To simplify, we provided total percentages of $\mathrm{L}^{*}, \mathrm{a}^{*}$, and $\mathrm{b}^{*}$ deterioration on $2 \% \mathrm{AL}+0.5 \% \mathrm{CBEO}, 2 \% \mathrm{AL}$, and control samples. $\mathrm{L}^{*}$ deterioration was respectively $15.24 \%, 19.1 \%$, $20.38 \%$; a* deterioration was $21.48 \%, 44.41 \%$, $62.15 \%$; and $b^{*}$ deterioration was $40.72 \%, 64.98 \%$, $64.74 \%$. These results showed that coating prevented color deterioration. Uncoated samples represented the lowest values of $\mathrm{L}^{*}, \mathrm{a}^{*}$, and $\mathrm{b}^{*}$ (fruit was the darkest, the least red, and the least yellow), and 2\%AL+0.5\%CBEO samples exhibited the best performance in retaining $\mathrm{L}^{*}, \mathrm{a}^{*}$, and $\mathrm{b}^{*}$ values, closer to those at harvest time, leading to the suggestion that $2 \% \mathrm{AL}+0.5 \% \mathrm{CBEO}$ is more efficient than $2 \% \mathrm{AL}$ to preserve natural color of strawberry, shown in Table 1 . Changes in $\mathrm{a}^{*}$ and $b^{*}$ values are a sign of oxidative browning, which means the coatings are able to maintain the red-yellow color by preventing oxidation and enzymatic browning. Changes in the values of $\mathrm{L}^{*}$, $a^{*}$, and $b^{*}$ are an indicative of oxidative reaction. The oxidative reaction will induce enzymatic and non-enzymatic browning effect, leading to loss of fruit's natural color. The presence of coating on the fruit surface contributes to maintain the orangered color of the fruit by preventing oxidation and browning enzymatic reactions.
Effect of edible coating on chemical attribute and flavor preferences

Total soluble solids (TSS) increased in all samples throughout time, and by the end of storage, TSS in 2\%AL+0.5\%CBEO was the lowest (35.18\% increment) followed by 2\%AL (40.39\% increment, and the highest was found in control samples ( $45.12 \%$ increment). TSS values for each storage interval are showed in Table 1 . The samples of $2 \% A L+0.5 \%$ CBEO kept a steady TSS level during the whole storage time, while TSS in control and 2\%AL samples increased significantly. By day 3 to day 5, TSS in all uncoated samples was higher $(\mathrm{P}<0.05)$ compared to the coated samples. Considering that the TSS value is in line with maturity level, therefore, fruit that has the highest TSS value is at the highest level of maturity, consequently, potential reason for lower TSS/ lower rate of increment in coated fruit is the reduction of respiration and metabolic activity, which may delay the ripening process. Martiñon et al. (2014) reported that the absence of high TSS is an indicator of poor fruit quality. Fruit store carbohydrates as a material and energy supply to carry out their activities. The change in TSS content might be due to the solubilization of the cell wall polyuronides and hemicelluloses in ripe strawberries (HernándezMuñoz et al., 2008). Moreover, during postharvest storage, metabolic processes continue as a result of fruit ripening and senescence, which continues by converting starch and organic acids to sugars to be used in the metabolic processes (Duan et al., 2011).

There were no particular trends towards the effect of coating on the acidity level $(\mathrm{P}>0.05)$. Nevertheless, during the last 3 days of storage, acidity levels were found to be significantly different between samples, which can be seen in Table 1 . The uncoated samples exhibited the highest value of acidity, which was i $58 \%$, followed by $2 \% \mathrm{AL}$ samples, which was $1.47 \%$, while the lowest was in 
$2 \% \mathrm{AL}+0.5 \% \mathrm{CBEO}$, which was $1.26 \%$. Velickova et al. (2013) and Sogvar et al. (2016) have reported that the acid content decreased continuously throughout time. However, in our case, acidity levels fluctuated, went up, and went down. Accordingly, in this study, the acidity level was continued to be observed for every storage interval.

Percentage of citric acid was up and down in all samples during storage, shown in Table 1. This result is in contrary to the statement of Pelayo et al. (2003), concluding that the titratable acidity of strawberry decreases during storage. Acidity level is directly related to the amount of organic acid content of fruit. The concentration of organic acids decreases during postharvest storage periods due to their use as a substrate in the respiration (Dong \& Wang, 2017) or their transformation into sugars (Fagundes et al., 2015). Therefore, the coating samples might reduced the rate of respiration by delaying the utilization of organic acids and consequently fruit maturity. The acidity level of uncoated samples decreased after 2 days of storage, while acidity level of coated samples decreased after 3 days of storage. Moreover, percentage of decline were lower in uncoated samples.

At the end of storage, uncoated samples had the highest acidity level due to the metabolic activity of microorganisms on strawberries that produce acid as a side product. Microorganisms on strawberry's surface produce volatile organic compounds. All volatile organic compounds could be chemically grouped into alcohols, esters, alkanes, alkenes, alkynes, organic acids, ketones, terpenoids, aldehydes and sulfur compounds (Qin et al., 2017). The acids contributed to the number of detected acids in the measurement. Fewer microorganisms in the coated sample imply a smaller additional source of acid. In line with our findings, detected acid was lower in our assessment. This behavior is also confirmed by Dong \& Wang (2017) and Vieira et al. (2016), in which the increment of total acids was due to the increase of a fungal population, which produced a large number of metabolites and acid mucus. It is important to mention that storage condition plays an important role on strawberry shelf-life, and some studies have been conducted at a lower temperature, while our study conducted under compatible temperatures for the tropics $\left(27 \pm 2^{\circ} \mathrm{C}\right)$ and at the same time under suitable temperatures for microbial growth. Therefore, the number of microbes in our study was higher.

The coating did not significantly $(\mathrm{P}>0.05)$ retain vitamin $\mathrm{C}$ content (Table 1). Surprisingly, the lowest vitamin $\mathrm{C}$ loss found in samples coated with $2 \% \mathrm{AL}$ alone, which was $0.12 \mathrm{~g}$ vitamin $\mathrm{C} / 100 \mathrm{~g}$, while vitamin $\mathrm{C}$ loss in samples coated with $2 \% \mathrm{AL}+0.5 \% \mathrm{CBEO}$ was $0.21 \mathrm{~g}$ vitamin $\mathrm{C} / 100 \mathrm{~g}$, and in uncoated samples was $0.3 \mathrm{~g}$ vitamin $\mathrm{C} / 100 \mathrm{~g}$ (Table 1). Dong \& Wang (2017) reported that the ascorbic acid content of all strawberries decreased during storage, and $\mathrm{CMC}$ incorporated with garlic essential oil treatment significantly inhibited the decrease of ascorbic acid. However, according to our study, incorporating coatings solution with cinnamon essential oil was not effective in maintaining vitamin C. Chemically, the EOs consist of terpene compounds (mono-, sesqui- and diterpenes), alcohols, acids, esters, epoxides, aldehydes, ketones, amines and sulfides (Bakkali et al., 2008). Since vitamin $\mathrm{C}$ is highly thermolabile and a highly sensitive component, a significant loss in $2 \% \mathrm{AL}+0.5 \% \mathrm{CBEO}$ could be linked to the addition of secondary compounds brought by cinnamon essential oil substances.

The uncoated samples earned the highest score, which was 95 (most preferred), followed by $2 \% \mathrm{AL}$ with a score of 70 , and the lowest was $2 \% A L+0.5 \% \mathrm{CBEO}$, which had a score of 65 , as shown in Figure 1. The flavor of coated samples was less desirable. CBEO gave a cinnamon flavor 


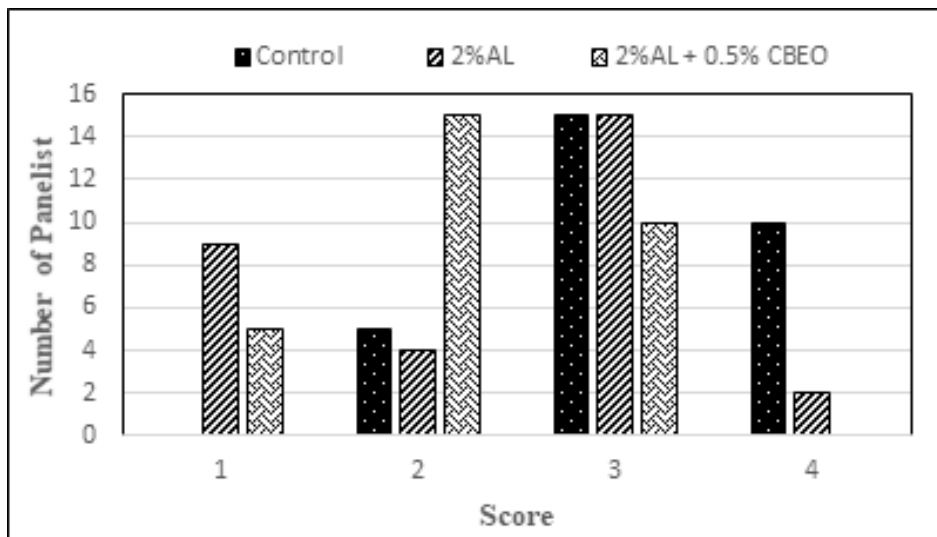

Figure 1. Effect of edible coating on flavor preferences score in postharvest strawberry fruit on the day after coating settlement. Number of panelist in each score which 1 represent most disliked and 4 represent most liked

to strawberries, which then eliminated the original microorganisms that grow on strawberries was flavor. Besides, coatings layers alone also blocked tested explicitly. The diameter of the clear zone forthe original flavor of strawberries. The sensory test mation is presented in Table 2. CBEO had the abilwas only performed once after an hour of coatings settlement. After two or three days of storage, uncoated samples released an unpleasant/rotten flavor due to the decaying process and the presence of microbe, while coated samples did not show any sign of a rotten flavor. In addition, the coating layers only affected flavor on the surface skin and had no effect on the flesh. However, further testing on flavor was not performed in this study.

\section{Effect on inhibition activity and total microbial growth}

The inhibition activity of antimicrobial agent ity to inhibit strawberry's spoilage microorganisms and reduce the number of microbial counts (Figure 2 ), or in another word, various microbes on strawberries were susceptible towards cinnamaldehyde substance. These factors are important, considering that the ability of pathogens to survive during storage or the presence of pathogens in the fruits will brings a risk of foodborne illnesses to consumer. A previous study by Zhang et al. (2015) confirmed the effectiveness of alginate coatings incorporated with $2 \%$ cinnamon essential oils in inhibiting the from Cinnamomum burmannii essential oil against growth of E. coli O157: H7, L. monocytogenes, and S.

Table 2. Antimicrobial activity against total microbial isolated from strawberries

\begin{tabular}{|c|c|c|c|c|c|c|c|c|c|}
\hline \multirow{2}{*}{ Component analysis } & & \multicolumn{8}{|c|}{ Dilution series (SD) } \\
\hline & & $10^{1}$ & $10^{2}$ & $10^{3}$ & $10^{4}$ & $10^{5}$ & $10^{6}$ & $10^{7}$ & $10^{8}$ \\
\hline \multicolumn{2}{|c|}{ Diameter of clear zone $(\mathrm{cm})$} & $\begin{array}{l}1.84 \\
(0.72)\end{array}$ & $\begin{array}{c}2.02 \\
(0.07)\end{array}$ & $\begin{array}{l}1.92 \\
(0.16)\end{array}$ & $\begin{array}{l}2.20 \\
(0.16)\end{array}$ & $\begin{array}{l}1.84 \\
(0.25)\end{array}$ & $\begin{array}{l}2.66 \\
(0.79)\end{array}$ & $n / c$ & $n / c$ \\
\hline \multirow{3}{*}{$\begin{array}{l}\text { Yeast/mold } \\
\left.\text { (logCFU mL }{ }^{-1}\right)\end{array}$} & Control & $\mathrm{n} / \mathrm{a}$ & $\mathrm{n} / \mathrm{a}$ & $\mathrm{n} / \mathrm{a}$ & $\begin{array}{l}6.31 \\
(0.04)\end{array}$ & $\begin{array}{l}7.10 \\
(0.03)\end{array}$ & $n / c$ & $n / c$ & $n / c$ \\
\hline & $2 \% \mathrm{AL}$ & $\mathrm{n} / \mathrm{a}$ & $n / a$ & $\mathrm{n} / \mathrm{a}$ & $\begin{array}{c}6.23 \\
(0.02)\end{array}$ & $\begin{array}{l}6.97 \\
(0.03)\end{array}$ & $\mathrm{n} / \mathrm{c}$ & $\mathrm{n} / \mathrm{c}$ & $\mathrm{n} / \mathrm{c}$ \\
\hline & $2 \% A L+0.5 \%$ CBEO & $n / a$ & $\mathrm{n} / \mathrm{a}$ & $\begin{array}{c}5.32 \\
(0.02)\end{array}$ & $\begin{array}{l}6.01 \\
(0.05)\end{array}$ & $\begin{array}{c}6.72 \\
(0.03)\end{array}$ & $n / c$ & $n / c$ & $\mathrm{n} / \mathrm{c}$ \\
\hline \multirow{3}{*}{$\begin{array}{l}\text { Mesophilic organism } \\
\left(\log \mathrm{CFU} \mathrm{mL}^{-1}\right)\end{array}$} & Control & $\mathrm{n} / \mathrm{a}$ & $\mathrm{n} / \mathrm{a}$ & $\mathrm{n} / \mathrm{a}$ & $\mathrm{n} / \mathrm{a}$ & $\mathrm{n} / \mathrm{a}$ & $\begin{array}{l}8.46 \\
(0.01)\end{array}$ & $\begin{array}{c}9.03 \\
(0.10)\end{array}$ & $\begin{array}{c}9.93 \\
(0.06)\end{array}$ \\
\hline & $2 \% \mathrm{AL}$ & $\mathrm{n} / \mathrm{a}$ & $\mathrm{n} / \mathrm{a}$ & $\mathrm{n} / \mathrm{a}$ & $\mathrm{n} / \mathrm{a}$ & $\begin{array}{l}7.44 \\
(0.02)\end{array}$ & $\begin{array}{l}8.16 \\
(0.03)\end{array}$ & $\begin{array}{l}8.91 \\
(0.05)\end{array}$ & $\begin{array}{l}9.62 \\
(0.12)\end{array}$ \\
\hline & $2 \% \mathrm{AL}+0.5 \% \mathrm{CBEO}$ & $\mathrm{n} / \mathrm{a}$ & $\mathrm{n} / \mathrm{a}$ & $\mathrm{n} / \mathrm{a}$ & $\begin{array}{c}6.34 \\
(0.02)\end{array}$ & $\begin{array}{l}7.10 \\
(0.02)\end{array}$ & $\begin{array}{l}7.89 \\
(0.02)\end{array}$ & $\begin{array}{l}8.81 \\
(0.11)\end{array}$ & $\begin{array}{c}9.54 \\
(0.12)\end{array}$ \\
\hline
\end{tabular}




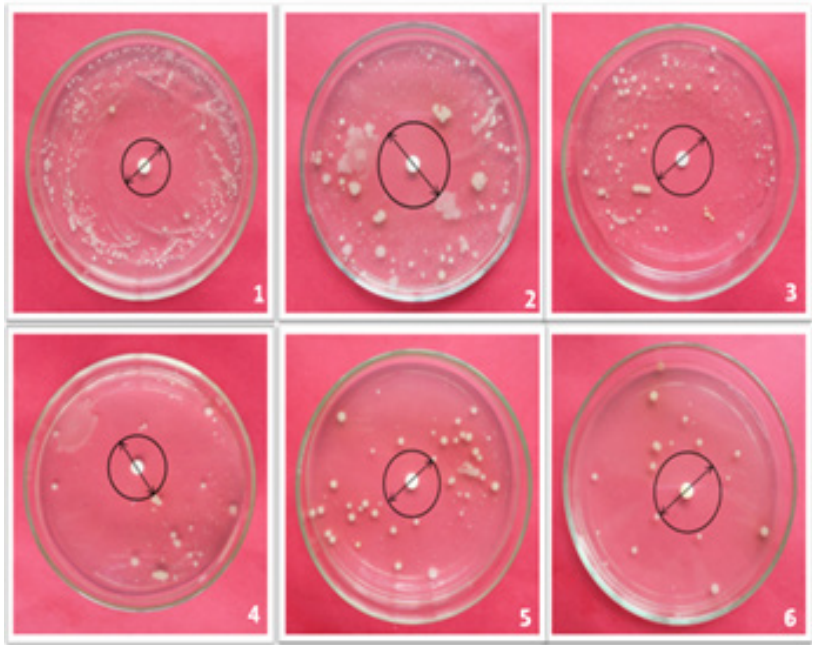

Figure 2. The inhibition activity of antimicrobial agent from Cinnamomum burmannii essential oil against microorganisms that grow on strawberries. Clear zone formedafter 24 hours of incubation period at $37^{\circ} \mathrm{C}$, number 1 to 6 indicate dilution series from $10^{1}$ to $10^{6}$

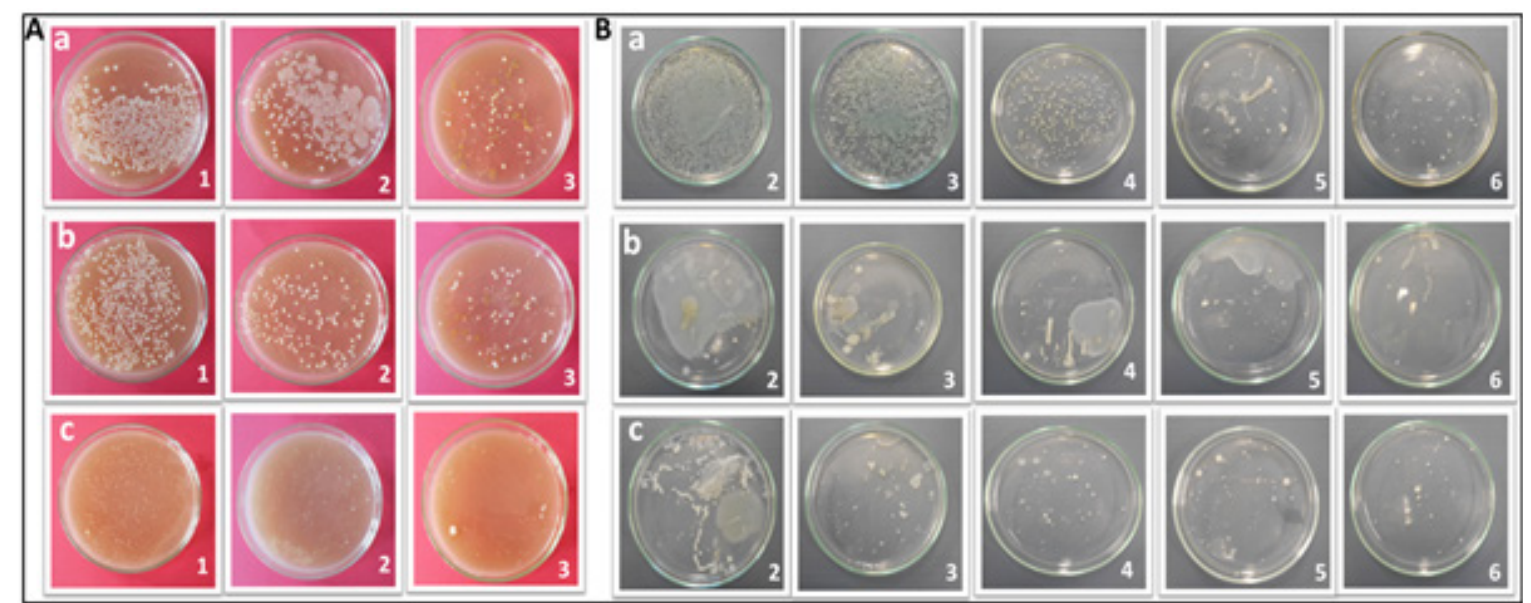

Figure 3. The number of yeast/mold colonies and aerobic mesophilic microorganisms for each treatment at selected dilution series. Colonies growth on agar after 48 hours incubation period at $35^{\circ} \mathrm{C}$, (A) Total yeast and molds (B) Total aerobic mesophilic microorganism, (a) control (b) 2\%AL (c) 2\%AL+0.5\%CBEO, number 1 to 6 indicate dilution series from 10-10

that cinnamon essential oil could be incorporated to alter microbial cell permeability, damage cytointo the sodium alginate/carboxymethylcellulose plasmic membranes, interfere with cellular energy film matrix to impart excellent antibacterial activity (ATP) generation system, and disrupt the proton against E. coli and S. Aureus. motive force. Hence, the disrupted permeability of

Cinnamon oil contains 50 - 60\% cinnamaldehyde and $4-7 \%$ eugenol (Matan et al., 2006). It has been proposed that cinnamaldehyde and eugenol can inhibit the production of an essential enzyme by the bacteria. Cinnamaldehyde can also damage the cell wall of bacteria (Helander et al., 1998; Matan et al., 2006). The mechanisms of inhibitory activity may relate to the ability of phenolic compounds the cytoplasmic membrane will lead to cell death (Calo et al., 2015).

Total yeast and molds $\left(\log \mathrm{CFU} \mathrm{mL} \mathrm{m}^{-1}\right)$ on the strawberries without treatment was $6.71,6.60$ in $2 \% A L$, and 6.02 in $2 \% A L+0.5 \% C B E O$. The number of yeast/mold colonies and aerobic mesophilic microorganisms for each treatment at selected dilution series are presented in Table 2. 

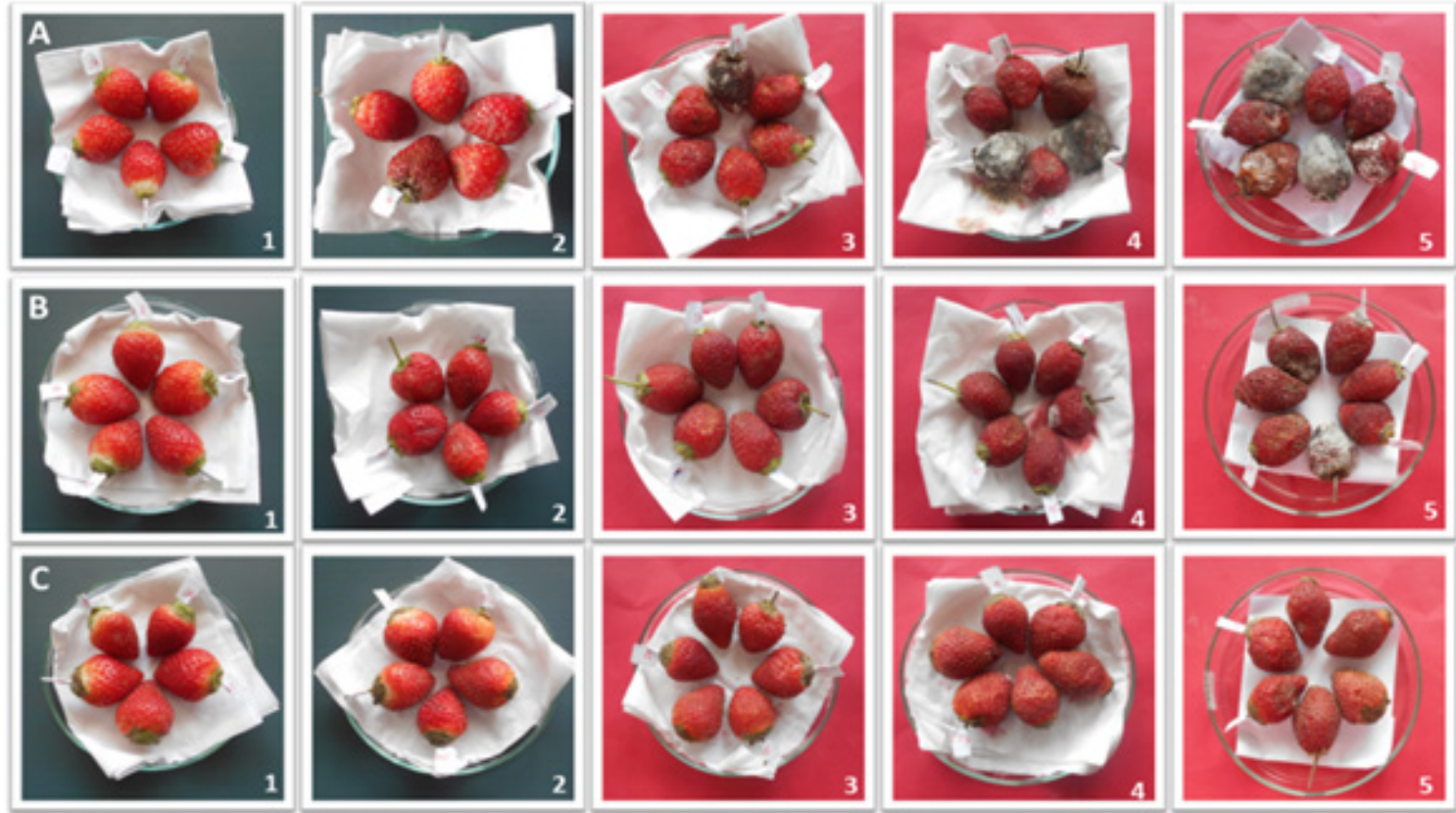

Figure 4. Effect of edible coatings on strawberry appearance during storage at $27 \pm 2^{\circ} \mathrm{C}$. (A) control (B) $2 \% \mathrm{AL}$ (C) $2 \% \mathrm{AL}+0.5 \% \mathrm{CBEO}$, number 1 to 5 indicate day 1 to day 5 of storage time

To simplify, the percentage of yeast and molds than uncoated samples). The fact that microbe was colonies was $44 \%$ in uncoated samples, $35 \%$ in $\mathrm{AL}$, and $21 \%$ in $\mathrm{AL}+\mathrm{CBEO}$. Total mesophilic microorganisms $\left(\log \mathrm{CFU} \mathrm{mL}^{-1}\right)$ on strawberries without treatment was $9.14,8.53$ in $2 \% A L$, and 7.93 in $2 \% A L+0.5 \% C B E O$. In sum, the percentage of mesophilic microorganism formed in agar plates was $52 \%$ on uncoated samples, $29 \%$ on AL samples, and $19 \%$ on $\mathrm{AL}+\mathrm{CBEO}$ samples, as shown in Figure 3. still able to grow in $2 \%$ AL samples may be due to the water-binding ability of alginate coating. This ability will provide a relatively moist environment, and it is beneficial for the survival of the bacteria (Remuñán-López \& Bodmeier, 1997).

\section{CONCLUSION}

Uncoated strawberries exhibited faster ripen-

According to our data, $2 \% \mathrm{AL}+0.5 \% \mathrm{CBEO}$ exhibited the best performance in inhibiting the growth of yeast and molds as well as the aerobic and mesophilic organisms in strawberries. This trend can be simply explained due to the presence of the cinnamaldehyde substance. A similar result has been reported by Martiñon et al. (2014), who confirmed that coatings incorporated with antibacterial agents (trans-cinnamaldehyde) were effective in inhibiting aerobic microorganisms during storage. Based on visual appearance, shown in Figure 4, coatings help maintain the natural quality attributes of strawberry (coated samples simply looked more fresh ing and faster deterioration in quality than coated strawberries. Edible coatings are effective in preventing weight loss, firmness loss, TSS changes, and discoloration, thereby leading to the improvement of the quality in general. However, edible coatings treatments did not show any significant effect on acidity levels and vitamin $\mathrm{C}$ content. In the other hand, the presence of the essential oil as antimicrobial agent also affected the natural flavor of strawberry, which was not prefered by the consumers. The findings of this study show that edible coating is a promising technique to preserve strawberries, especially under hot temperatures in the tropics land. Moreover, coatings enriched with 
the antimicrobial agent were effective in maintaining quality, especially based on physicochemical properties and the ability to reduce the number of living microorganisms on strawberry surfaces. To be specific, $2 \% \mathrm{AL}+0.5 \% \mathrm{CBEO}$ exhibited better performance than $2 \% \mathrm{AL}$ alone in maintaining quality attributes of strawberry. The scope of this study was designed for strawberries in the common tropic condition. Future study can explore more into variety of temperature control to maximize the utilization of the coatings and the material mixture to find the best concentration for the coating solution. Apart from that, future researchers can also focus on the effectiveness of different essential oils in various food matrices, target microorganisms, and storage condition. Furthermore, it is important for future researchers to study the synergism between essential oils and other compounds or others coating techniques before it can be applied commercially.

\section{ACKNOWLEDGMENTS}

The authors acknowledge the support in the form of providing laboratory equipment from the Department of Agro-industrial Technology, Universitas Gadjah Mada. The authors are thankful to Nicholas Tyack for the language assistance and to all the authors cited in this article.

\section{REFERENCES}

Bakkali, F., Averbeck, S., Averbeck, D., \& Idaomar, M. (2008). Biological effects of essential oils - A review. In Food and Chemical Toxicology (Vol. 46, Issue 2, pp. 446-475). https:// doi.org/10.1016/j.fct.2007.09.106

Bhaskara Reddy, M. V., Belkacemi, K., Corcuff, R., Castaigne, F., \& Arul, J. (2000). Effect of pre-harvest chitosan sprays on postharvest infection by Botrytis cinerea quality of strawberry fruit. In Postharvest Biology and Technology (Vol. 20, Issue 1, pp. 39-51). https://doi.org/10.1016/S0925-5214(00)00108-3

Calo, J. R., Crandall, P. G., O'Bryan, C. A., \& Ricke, S. C. (2015). Essential oils as antimicrobials in food systems - A review. Food Control, 54, 111-119. https://doi.org/10.1016/j.foodcont.2014.12.040

Chao, S. C., Young, D. G., \& Oberg, C. J. (2000). Screening for inhibitory activity of essential oils on selected bacteria, fungi and viruses.
Journal of Essential Oil Research, 12(5), 639-649. https://doi. org/10.1080/10412905.2000.9712177

Chiumarelli, M., \& Hubinger, M. D. (2014). Evaluation of edible films and coatings formulated with cassava starch, glycerol, carnauba wax and stearic acid. Food Hydrocolloids, 38, 20-27. https:// doi.org/10.1016/j.foodhyd.2013.11.013

Cian, R. E., Fajardo, M. A., Alaiz, M., Vioque, J., González, R. J., \& Drago, S. R. (2014). Chemical composition, nutritional and antioxidant properties of the red edible seaweed Porphyra columbina. International Journal of Food Sciences and Nutrition, 65(3), 299-305. https://doi.org/10.3109/09637486.2013.854746

Del-Valle, V., Hernández-Muñoz, P., Guarda, A., \& Galotto, M. J. (2005). Development of a cactus-mucilage edible coating (Opuntia ficus indica) and its application to extend strawberry (Fragaria ananassa) shelf-life. Food Chemistry, 91(4), 751-756. https:// doi.org/10.1016/j.foodchem.2004.07.002

Dong, F., \& Wang, X. (2017). Effects of carboxymethyl cellulose incorporated with garlic essential oil composite coatings for improving quality of strawberries. International Journal of Biological Macromolecules, 104, 821-826. https://doi.org/10.1016/j. ijbiomac.2017.06.091

Duan, J., Wu, R., Strik, B. C., \& Zhao, Y. (2011). Effect of edible coatings on the quality of fresh blueberries (Duke and Elliott) under commercial storage conditions. Postharvest Biology and Technology, 59(1), 71-79. https://doi.org/10.1016/j.postharvbio.2010.08.006

Espitia, P. J. P., Du, W. X., Avena-Bustillos, R. de J., Soares, N. de F. F., \& McHugh, T. H. (2014). Edible films from pectin: Physicalmechanical and antimicrobial properties - A review. In Food Hydrocolloids (Vol. 35, pp. 287-296). https://doi.org/10.1016/j. foodhyd.2013.06.005

Fagundes, C., Moraes, K., Pérez-Gago, M. B., Palou, L., Maraschin, M., \& Monteiro, A. R. (2015). Effect of active modified atmosphere and cold storage on the postharvest quality of cherry tomatoes. Postharvest Biology and Technology, 109, 73-81. https://doi. org/10.1016/j.postharvbio.2015.05.017

Fan, Y., Xu, Y., Wang, D., Zhang, L., Sun, J., Sun, L., \& Zhang, B. (2009). Postharvest Biology and Technology Effect of alginate coating combined with yeast antagonist on strawberry ( Fragaria × ananassa ) preservation quality. 53, 84-90. https://doi. org/10.1016/j.postharvbio.2009.03.002

Gol, N. B., Patel, P. R., \& Rao, T. V. R. (2013). Improvement of quality and shelf-life of strawberries with edible coatings enriched with chitosan. Postharvest Biology and Technology, 85, 185-195. https://doi.org/10.1016/j.postharvbio.2013.06.008

Guerreiro, A. C., Gago, C. M. L., Faleiro, M. L., Miguel, M. G. C., \& Antunes, M. D. C. (2015). The use of polysaccharide-based edible coatings enriched with essential oils to improve shelf-life of strawberries. Postharvest Biology and Technology, 110, 51-60. https://doi.org/10.1016/j.postharvbio.2015.06.019

Han, Y., Yu, M., \& Wang, L. (2017). Physical and antimicrobial properties of sodium alginate/carboxymethyl cellulose films incorporated with cinnamon essential oil. Food Packaging and Shelf Life, October 2016, 1-8. https://doi.org/10.1016/j. fpsl.2017.11.001

Helander, I. M., Alakomi, H.-L., Latva-Kala, K., Mattila-Sandholm, T., Pol, I., Smid, E. J., Gorris, L. G. M., \& von Wright, A. (1998). 
Characterization of the Action of Selected Essential Oil Components on Gram-Negative Bacteria. Journal of Agricultural and Food Chemistry, 46(9), 3590-3595. https://doi.org/10.1021/ jf980154m

Hernández-Muñoz, P., Almenar, E., Valle, V. Del, Velez, D., \& Gavara, R. (2008). Effect of chitosan coating combined with postharvest calcium treatment on strawberry (Fragaria $\times$ ananassa) quality during refrigerated storage. Food Chemistry, 110(2), 428-435. https://doi.org/10.1016/j.foodchem.2008.02.020

Hunter Laboratories. (2012). Measuring Color using Hunter L, a, b versus CIE 1976 L*a*b*. Hunter Lab, 4. https://doi. org/10.1128/AEM.02997-13

Martinez-Ferrer, M., Нагрег, C., Perez-Munoz, F., \& Chaparro, M. (2002). Modified atmosphere packaging of minimally processed mango and pineapple fruits. Journal of Food Science, 67(9), 3365-3371. https://doi.org/10.1016/j.postharvbio.2013.06.019

Martiñon, M. E., Moreira, R. G., Castell-Perez, M. E., \& Gomes, C. (2014). Development of a multilayered antimicrobial edible coating for shelf-life extension of fresh-cut cantaloupe (Cucumis melo L.) stored at $4^{\circ} \mathrm{C}$. LWT - Food Science and Technology, 56(2), 341-350. https://doi.org/10.1016/j.Iwt.2013.11.043

Matan, N., Rimkeeree, H., Mawson, A. J., Chompreeda, P., Haruthaithanasan, V., \& Parker, M. (2006). Antimicrobial activity of cinnamon and clove oils under modified atmosphere conditions. International Journal of Food Microbiology, 107(2), 180-185. https://doi.org/10.1016/j.ijfoodmicro.2005.07.007

Maturin, L \& Peeler, J. T. (2001). Bacteriological Analytical Manual: Aerobic Plate Count. U.S. Food and Drug Administration.

Nair, M. S., Saxena, A., \& Kaur, C. (2020). Effect of chitosan and alginate based coatings enriched with pomegranate peel extract to extend the postharvest quality of guava ( Psidium guajava L .) E ff ect of chitosan and alginate based coatings enriched with pomegranate peel extract to extend the postharvest quality of guava ( Psidium guajava L .). Food Chemistry, 240(July 2017), 245-252. https://doi.org/10.1016/j.foodchem.2017.07.122

Nazoori, F., Poraziz, S., Mirdehghan, S. H., Esmailizadeh, M., \& Zamanibahramabadi, E. (2020). Improving Shelf Life of Strawberry Through Application of Sodium Alginate and Ascorbic Acid Coatings Introduction. International Journal of Horticultural Science and Technology, 7(3), 279-293. https://doi.org/10.22059/ ijhst.2020.297134.341

Pelayo, C., Ebeler, S. E., \& Kader, A. A. (2003). Postharvest life and flavor quality of three strawberry cultivars kept at $5^{\circ} \mathrm{C}$ in air or air+20 kPa CO2. Postharvest Biology and Technology, 27(2), 171-183. https://doi.org/10.1016/S0925-5214(02)00059-5

Qin, X., Xiao, H., Cheng, X., Zhou, H., \& Si, L. (2017). Hanseniaspora uvarum prolongs shelf life of strawberry via volatile production. Food Microbiology, 63, 205-212. https://doi.org/10.1016/j. fm.2016.11.005

Raeisi, M., Tajik, H., Yarahmadi, A., \& Sanginabadi, S. (2015). Antimicrobial Effect of Cinnamon Essential Oil Against Escherichia Coli and Staphylococcus aureus Antimicrobial Effect of Cinnamon Essential Oil Against Escherichia Coli and Staphylococcus aureus. January 2016. https://doi.org/10.17795/jhealthscope-21808

Remuñán-López, C., \& Bodmeier, R. (1997). Mechanical, water uptake and permeability properties of crosslinked chitosan gluta- mate and alginate films. Journal of Controlled Release, 44(2-3), 215-225. https://doi.org/10.1016/S0168-3659(96)01525-8 Romanazzi, G. (2010). Chitosan Treatment for the Control of Postharvest Decay of Table Grapes, Strawberries and Sweet Cherries. Fresh Produce, 4(1), 111-115.

Seow, Y. X., Yeo, C. R., Chung, H. L., \& Yuk, H.-G. (2014). Plant Essential Oils as Active Antimicrobial Agents. Critical Reviews in Food Science and Nutrition, 54(5), 625-644. https://doi.org/1 $0.1080 / 10408398.2011 .599504$

Sogvar, O. B., Koushesh Saba, M., \& Emamifar, A. (2016). Aloe vera and ascorbic acid coatings maintain postharvest quality and reduce microbial load of strawberry fruit. Postharvest Biology and Technology, 114, 29-35. https://doi.org/10.1016/j. postharvbio.2015.11.019

Tavassoli-Kafrani, E., Shekarchizadeh, H., \& Masoudpour-Behabadi, M. (2016). Development of edible films and coatings from alginates and carrageenans. In Carbohydrate Polymers (Vol. 137, pp. 360-374). https://doi.org/10.1016/j.carbpol.2015.10.074 Tharanathan, R. N., \& Kittur, F. S. (2003). Chitin - The Undisputed Biomolecule of Great Potential. In Critical Reviews in Food Science and Nutrition (Vol. 43, Issue 1, pp. 61-87). https://doi. org/10.1080/10408690390826455

Valero, D., Díaz-Mula, H. M., Zapata, P. J., Guillén, F., Martínez-Romero, D., Castillo, S., \& Serrano, M. (2013). Effects of alginate edible coating on preserving fruit quality in four plum cultivars during postharvest storage. Postharvest Biology and Technology, 77, 1-6. https://doi.org/10.1016/j.postharvbio.2012.10.011

Velickova, E., Winkelhausen, E., Kuzmanova, S., Alves, V. D., \& Moldão-Martins, M. (2013). Impact of chitosan-beeswax edible coatings on the quality of fresh strawberries (Fragaria ananassa cv Camarosa) under commercial storage conditions. LWT - Food Science and Technology, 52(2), 80-92. https://doi. org/10.1016/j.Iwt.2013.02.004

Vieira, J. M., Flores-López, M. L., de Rodríguez, D. J., Sousa, M. C., Vicente, A. A., \& Martins, J. T. (2016). Effect of chitosan-Aloe vera coating on postharvest quality of blueberry (Vaccinium corymbosum) fruit. Postharvest Biology and Technology, 116, 88-97. https://doi.org/10.1016/j.postharvbio.2016.01.011

Vu, C. H. T., \& Won, K. (2013). Novel water-resistant UV-activated oxygen indicator for intelligent food packaging. Food Chemistry, 140(1-2), 52-56. https://doi.org/10.1016/j.foodchem.2013.02.056

Vu, K. D., Hollingsworth, R. G., Leroux, E., Salmieri, S., \& Lacroix, M. (2011). Development of edible bioactive coating based on modified chitosan for increasing the shelf life of strawberries. Food Research International, 44(1), 198-203. https://doi. org/10.1016/j.foodres.2010.10.037

Zactiti, E. M., \& Kieckbusch, T. G. (2006). Potassium sorbate permeability in biodegradable alginate films: Effect of the antimicrobial agent concentration and crosslinking degree. Journal of Food Engineering, 77(3), 462-467. https://doi.org/10.1016/j. jfoodeng.2005.07.015

Zhang, Y., Ma, Q., Critzer, F., Davidson, P. M., \& Zhong, Q. (2015). Effect of alginate coatings with cinnamon bark oil and soybean oil on quality and microbiological safety of cantaloupe. International Journal of Food Microbiology, 215, 25-30. https://doi. org/10.1016/j.ijfoodmicro.2015.08.014 